\title{
COMMENTS
}

\section{Conditioning Forum Non Conveniens}

\author{
John Bies $\dagger$
}

On the night of December 2, 1984, methyl isocynate, a highly toxic gas, began to leak in substantial quantity from an insecticide plant in Bhopal, India, owned by Union Carbide India Limited ("UCIL"). Winds carried this deadly gas into some of the most densely populated areas of the city, eventually resulting in over two thousand deaths and over two hundred thousand injuries. By December 7,1984, Indian plaintiffs had filed suit in the United States against Union Carbide Corporation, the majority shareholder in UCIL. ${ }^{1}$ The district court hearing the consolidated action resulting from these suits ultimately dismissed the case under the doctrine of forum non conveniens, ${ }^{2}$ and this dismissal was upheld by the Second Circuit, ${ }^{3}$ effectively denying the plaintiffs an opportunity to vindicate their legal rights in a U.S. federal court.

The explosion of international civil litigation in U.S. courts has rendered the course followed by this case typical. Foreign plaintiffs are increasingly drawn to the substantive and procedural advantages of U.S. courts, and the growing importance of international commerce has increased the number of international cases in which federal jurisdiction is proper. ${ }^{4}$ In response to this eruption of international civil

$\dagger$ B.A. 1993, Pomona College; M.A. (Political Science) 1997, University of Minnesota; J.D. Candidate 2000, The University of Chicago.

1 See In re Union Carbide Corp Gas Plant Disaster at Bhopal, India, 634 F Supp 842, 844 (S D NY 1986), affd in part, modified in part, $809 \mathrm{~F} 2 \mathrm{~d} 195$ (2d Cir 1987).

$2634 \mathrm{~F}$ Supp at 867.

3 In re Union Carbide Corp Gas Plant Disaster at Bhopal, India, 809 F2d 195, $205-06$ (2d Cir 1987).

4 As aptly stated by Lord Denning, "As a moth is drawn to light, so is a litigant drawn to the United States." Smith Kline \& French Laboratories Ltd v Block, [1983] 1 WLR 730, 733, [1983] 2 All E R 72, 74 CCA 1983. For the impact of international commerce on the dockets of U.S. courts, see Daniel J. Dorward, Comment, The Forum Non Conveniens Doctrine and the Judi- 
litigation, federal courts have increasingly relied on the doctrine of forum non conveniens to moderate the exercise of their jurisdiction in cases having little relationship to the forum. The courts deploy the doctrine to mitigate against foreign plaintiffs' incentives to choose a U.S. forum. ${ }^{s}$

A significant feature of the decision in the Union Carbide case is the fact that the court did not simply dismiss the case. Rather, it conditioned the dismissal on the moving defendant accepting a number of concessions, such as submission to personal jurisdiction in the alternate forum, waiver of any statute of limitations defenses, and compliance with discovery under the U.S. Federal Rules of Civil Procedure. ${ }^{6}$ In doing so, the court reflected a growing trend of imposing conditions on defendants when granting forum non conveniens dismissals.

However, while the use of conditions is becoming a common feature of forum non conveniens dismissals, current case law lacks a reasoned analysis of when such conditions are appropriate, or where the authority to impose them originates. This failure to provide reasoning for the imposition of conditions appears particularly problematic given the discretionary (and judicially crafted) character of the forum non conveniens doctrine. Trial courts' ability to impose such conditions poses certain questions. First, what is the range of conditions that federal district courts can properly attach to such dismissals? Second, what principles, if any, guide courts in determining what circumstances warrant the use and selection of conditions? Finally, what is the source of courts' authority to impose such conditions? Unfortunately, the pattern of conditions imposed by various district courts seems incoherent. The trend toward the imposition of conditions in the forum non

cial Protection of Multinational Corporations from Forum Shopping Plaintiffs, $19 \mathrm{U} \mathrm{Pa}$ J Intl Econ L 141, 142 (1998) (noting the dramatic increase in foreign disputes in U.S. courts); Gary B. Born with David Westin, International Civil Litigation in United States Courts: Commentary and Materials 1 (Kluwer 2d ed 1992) (noting that the growing importance of international commerce has rendered litigation involving foreign parties standard fare for U.S. courts). For an explanation of why U.S. courts are attractive to foreign plaintiffs, see Dorward, $19 \mathrm{U} \mathrm{Pa} \mathrm{J} \mathrm{Intl} \mathrm{Econ} \mathrm{L} \mathrm{at} \mathrm{146-}$ 50; Linda J. Silberman, Developments in Jurisdiction and Forum Non Conveniens in International Litigation: Thoughts on Reform and a Proposal for a Uniform Standard, 28 Tex Intl L J 501, 50203 (1993); Laurel E. Miller, Comment, Forum Non Conveniens and State Control of Foreign Plaintiff Access to U.S. Courts in International Tort Actions, 58 U Chi L Rev 1369, 1369 (1991).

5 On the use of forum non conveniens by U.S. courts to manage their dockets, see Dorward, $19 \mathrm{U}$ Pa J Intl Econ L at 142,158-64 (cited in note 4) (describing the development and history of forum non conveniens in the United States); Born, International Civil Litigation at 276-77 (cited in note 4) (outlining the development of modern forum non conveniens doctrine); Miller, $58 \mathrm{U}$ Chi L Rev at 1369 (cited in note 4) (describing how federal courts use forum non conveniens to clear their dockets, and noting that consequently, foreign plaintiffs often sue in state court).

$6634 \mathrm{~F}$ Supp at 867 . Note that these conditions were modified on appeal by the Second Circuit, 809 F2d at 205-06, as discussed below in text accompanying notes 72-75.

7 See Part I.C.1. 
conveniens context appears to lack any organizing principle, and there is no settled law on what would constitute an abuse of discretion in the imposition of such conditions.

This Comment argues that the history and purposes of the doctrine of forum non conveniens suggest an answer to these questions ${ }^{9}-$ that trial courts appropriately impose conditions on forum non conveniens dismissals when the conditions prevent dismissals from unduly penalizing plaintiffs who acted reasonably in pursuing their legal rights in a U.S. forum. As this proposal draws on the common law history of the appropriate place of trial, Part I begins by tracing the historical development of the doctrine of forum non conveniens at British common law, continues by describing the contours of modern forum non conveniens doctrine in the federal courts, and then concludes with a description of the growing use of conditions to shape the effect of forum non conveniens dismissals. Part II considers institutional and historical sources of guidance in seeking principles that might cabin the otherwise unconstrained discretion of judges to condition forum non conveniens dismissals. Finally, Part III proposes a way to limit trial courts' discretion in imposing conditions on forum non conveniens dismissals based upon both the historical sources of the doctrine and its normative underpinnings.

In the end, this Comment argues that the practice of using conditions to shape the effects of venue changes is nothing new, but instead is actually quite old (perhaps even inherent in the traditional practice of forum non conveniens dismissals). This history can both inform and discipline the use of conditions, thereby providing the rigor and guidance that modern practice currently lacks. While the discretionary nature of forum non conveniens dismissals prevents rule-like constraints on the imposition of conditions, a principle of protecting the plaintiff's position at the time of dismissal, thereby minimizing any undue burdens associated with the change in forum, ought to guide trial courts in dictating the conditions upon which dismissal will be granted. This principle reflects a return to the historical bases of forum non conveniens dismissals, not a departure from them..$^{10}$

8 See Part I.C.2.

9 In addressing these questions, this Comment will be limited to U.S. federal court practices, although the same logic might apply in state court cases.

10 While history supports the imposition of conditions, express legislative acquiescence in these acts of judicial discretion through the enactment of pertinent jurisdictional statutes would reinforce the legitimacy of both issuing forum non conveniens dismissals and placing conditions on them. 


\section{THE DOCTRINE OF FORUM NON CONVENIENS}

Forum non conveniens is a doctrine under which a court with proper subject matter jurisdiction, personal jurisdiction, and venue in a suit nevertheless declines to exercise its jurisdiction. As the Supreme Court explained in Gulf Oil Corp v Gilbert, the "principle of forum non conveniens is simply that a court may resist imposition upon its jurisdiction even when jurisdiction is authorized by the letter of a general venue statute." ${ }^{\prime 2}$ As we will see, the development of this principle followed a complicated path.

\section{A. The Historical Foundations of Forum Non Conveniens}

1. Origins and development in British law.

The origin of the doctrine of forum non conveniens, though uncertain, is typically traced to early Scottish decisions. ${ }^{13}$ However, before turning to these Scottish cases, placing forum non conveniens within the wider context of determining the appropriate place of trial for a civil action best explains the scope and development of the doctrine. The early development of the common law on the appropriate place of trial for a civil action, now known as the rules of venue, proceeded from evolving understandings of the role of the jury. As the jury evolved from a fact-reporting body to a fact-trying body, there was less need to tie the place of trial to the place in which the facts at issue arose. ${ }^{14}$ Where actions were deemed "transitory" by the court,

11330 US 501 (1947).

12 Id at 507.

13 See American Dredging Co v Miller, 510 US 443, 449 (1994) (tracing forum non conveniens to Scottish law); Piper Aircraft Co v Reyno, 454 US 235, 248 n 13 (1981) (same). See also Peter J. Carney, International Forum Non Conveniens: "Section 1404.5"-A Proposal in the Interests of Sovereignty, Comity, and Individual Justice, 45 Am U L Rev 415, 424-25 (1995) (noting that most accounts say that the doctrine originated as an equitable remedy in Scottish law and briefly describing the features of the doctrine and its original purpose); Alexander Reus, Judicial Discretion: A Comparative View of the Doctrine of Forum Non Conveniens in the United States, the United Kingdom, and Germany, 16 Loy LA Intl \& Comp L J 455, 459 (1994) (same); Paula K. Speck, Forum Non Conveniens and Choice of Law in Admiralty: Time for an Overhaul, $18 \mathrm{~J}$ Marit L \& Comm 185, 187-88 (1987) (tracing separate development of doctrine in Scottish and English law and noting distinctive features of each jurisdiction's doctrine); Edward L. Barrett, Jr., The Doctrine of Forum Non Conveniens, 35 Cal L Rev 380, 386-87 (1947) (noting the "obscure" origins of forum non conveniens and explaining that the term was first used by Scottish courts to dismiss cases better suited to another forum); Robert Braucher, The Inconvenient Federal Forum, 60 Harv L Rev 908, 909 (1947). But see Joseph Dainow, The Inappropriate Forum, 29 Ill L Rev 867, 881 \& n 58 (1935) (implying without authority that the doctrine was "borrowed" by the Scots).

14 See Roger S. Foster, Place of Trial-Interstate Application of Intrastate Methods of Adjustment, 44 Harv L Rev 41, 43 \& n 2 (1930), citing Henry John Stephen, $A$ Treatise on the Principles of Pleading in Civil Actions: Comprising a Summary of the Whole Proceedings in a Suit at Law 315-28 (Harvard 1895); W.S. Holdsworth, 5 A History of English Law 117-19, 140-42 (Metheun 1923); W.S. Holdsworth, 3 A History of English Law 654 (Metheun 1923); Austin 
they became cognizable in courts beyond the locale of the events in question, effectively freeing the plaintiff in a transitory action to designate any county in England as the place of trial. ${ }^{15}$

Once plaintiffs obtained the power to determine venue, that power was inevitably abused. ${ }^{16}$ Forum shopping by plaintiffs seeking to create inconvenience to the defendant is not new, nor are efforts to curb it. Several early efforts were made to restrain plaintiffs' abuse of choice of forum. ${ }^{17}$ These efforts culminated in the creation of a motion for change of venue by the defendant, available "where the cause arose exclusively in one county and the plaintiff had designated another." The power to change venue eventually expanded to allow common law courts discretion "to change venue for the convenience of witnesses," although "the burden of overcoming the inertia of the court" rested on the defendant.

Courts were eventually confronted with the question of the appropriateness of venue where the alternative was not simply another county, but another country. The discretion of the court to decline jurisdiction under the doctrine of forum non conveniens developed in response to this situation. While the precise origins of the doctrine remain unclear, in some early Scottish cases the plea of forum non competens-a plea that typically contended that the court lacked jurisdictional competence-was sustained where jurisdiction seemed clear, but the parties were foreign and trial seemed inconvenient. ${ }^{20} \mathrm{By}$

Wateman Scott, Fundamentals of Procedure in Actions of Law 18-23 (Baker, Voorhis 1922); James Bradley Thayer, Preliminary Treatise on Evidence at the Common Law ch 2 (Little, Brown 1898); William Tidd, The Practice of the Court of King's Bench in Personal Actions with Reference to Cases of Practice in the Court of Common Pleas 10-13 (H. Bryer 1st ed 1795).

15 Foster, 44 Harv L Rev at 43 (cited in note 14). See also Roger S. Foster, Place of Trial in Civil Actions, 43 Harv L Rev 1217, 1218 (1930) (explaining and criticizing the distinction between "local" and "transitory" causes of action in determining venue). See, for example, Mostyn $v$ Fabrigas, 1 Cowp 161, 170-81 (K B 1774), where the plaintiff was allowed to bring a trespass and false imprisonment case in England against a native of Minorca for acts committed in Minorca.

16 Foster, 44 Harv L Rev at 43 (cited in note 14), citing Holdsworth, 5 A History of English Law at 117 (cited in note 14).

17 See Foster, 44 Harv L Rev at 43-44 (cited in note 14) (discussing a statute of Richard II that "unsuccessfully" attempted to "keep the venue local," a statute of Henry IV that directed that attorneys be sworn that "they make no suit in a foreign county" and various rules of court that punished attorneys for filing such suit), citing 6 Rich II, c 2 (1382) and 4 Hen IV, c 18 (1402).

18 See Foster, 44 Harv L Rev at 44 . The plaintiff, however, could block the transfer "by undertaking to give material evidence arising in the county where he had laid [the suit]." Id.

19 See id at 44-45. See also Foster v Taylor, 1 Durnf \& East 781, 782 (K B 1787) (changing venue of case for the convenience of witnesses despite evidence in the initial forum).

20 See, for example, Vernor $v$ Elvies, 6 Mor Dict of Dec 4788 (Sess 1610) (refusing to hear a case involving two Englishmen); Col Brog's Heir v _.., 6 Mor Dict of Dec 4816 (Sess 1639) (refusing to grant process against Scotsman residing in Holland, with goods and land in Scotland, because the testator had lived in Holland and all the goods in dispute were there). See also Barrett, $35 \mathrm{Cal}$ L Rev at $387 \mathrm{n} 35$ (cited in note 13) ("In a few very early Scottish cases the plea of forum non competens ... was sustained in cases where the jurisdiction seemed clear but the par- 
the early nineteenth century, Scottish estate courts increasingly recognized that the question in these pleas included not simply the competence of jurisdiction but also the expediency of trial in the forum, entailing an assessment of which forum "is the proper forum for accounting." ${ }^{21}$ As the courts began to recognize convenience and expediency as distinct from competence of jurisdiction, they began to refer to this new discretionary refusal of jurisdiction as "forum non conveniens." ${ }^{22}$. These decisions became the foundation for the development of the doctrine in Scotland, ${ }^{23}$ though the leading English case traced the court's discretionary power to Chancery Court decisions that recognized the power of equity courts to stay vexatious suits. ${ }^{24}$

ties were nonresidents and trial in Scotland would have been inconvenient."); John Trayner, Latin Maxims and Phrases 220 (Green 2d ed 1876) ("Forum non competens").

21 McMorine v Cowie, 7 Sess Cas (2d Ser) 270, 272 (1845). See also Macmaster v Macmaster, 11 Sess Cas (1st Ser) 685, 687-88 (1833) (holding that an action for accounting would not be sustained despite adequacy of jurisdiction because both the estates to be accounted and the defendants were located abroad); Parken v Royal Exchange Assurance Co, 8 Sess Cas (2d Ser) 365, 369-70 (1846) (noting that the defendant's plea should be interpreted as arguing that the Scottish courts were inappropriate because the "tribunals of another country" were better suited to make the determination); Tulloch $v$ Williams, 8 Sess Cas (2d Ser) 657, 659 (1846) (recognizing that the question is one of inconvenience and not incompetence); Longworth $v$ Hope, 3 Sess Cas (3d Ser) 1049, 1053 (1865) ("The next question is the question of forum non competens. Now the plea usually thus expressed does not mean that the forum is one in which it is wholly incompetent to deal with the question. The plea has received a wide signification, and is frequently stated in reference to cases in which the Court may consider it more proper for the ends of justice that the parties should seek their remedy in another forum."); Clements $v$ Macaulay, 4 Sess Cas (3d Ser) 583,591-92 (1866) (interpreting a plea of forum non competens in a suit on a contract made in Texas by two Americans, over which Texas courts would not have jurisdiction, to mean "this Court is an inconvenient and improper forum," not "Texas is the only proper forum").

22 See Macadam $v$ Macadam, 11 Sess Cas (3d Ser) 860, $861 \mathrm{n} *, 862$ (1873) for an early use of the term forum conveniens. See also Brown v Cartwright, 20 Scot L R 818, 819-20 (Sess 1883) ("[I]t is further pleaded, that assuming that the Scottish Court had jurisdiction, yet it is forum non conveniens."); Williamson v North-Eastern Railway Co, 21 Scot L R 421, 422 (Sess 1884) ("[T]he jurisdiction of this Court is undeniable. Apart, however, from the question of jurisdiction, we are always entitled to consider the question of forum conveniens, which includes ... whether this is the most convenient forum for trying the case."); La Sociéte du Gaz de Paris v La Société Anonyme de Navigation "Les Armateurs Français", [1925] Sess Cas 332, 344, affd, [1926] Sess Cas (H L) 13 ("In the earlier cases the plea was thus stated-forum non competens. But it was recognized that that was an inaccurate statement of the plea .... And so the form of the plea was altered, and it was stated ... as forum non conveniens."). For a general overview of British doctrine, see Andrew Dewar Gibb, The International Law of Jurisdiction in England and Scotland 212-30 (Hodge 1926); W.M. Gloag and R. Candlish Henderson, Introduction to the Law of Scotland 22-23 (Green 3d ed 1939).

23 The fleshing out of this doctrine can be seen in the opinions in Société $d u$ Gaz, [1925] Sess Cas at 332, 344, 347; [1926] Sess Cas (H L) at 20-23 (noting that the court should follow the interests of justice in considering another forum).

24 See Logan v Bank of Scotland, [1906] 1 K B 141, 148-51. The court in Logan relies on three Chancery Court decisions recognizing the power of English equity courts to stay vexatious suits-McHenry v Lewis, 22 Ch D 397 (C A 1882), Peruvian Guzano Co v Bockwoldt, 23 Ch D 225 (C A 1883), and Hyman v Helm, 24 Ch D 531 (C A 1883)-to hold that English precedent permits discretionary dismissals, though perhaps less easily than the Scottish and American precedent it surveyed. 
The doctrine of forum non conveniens, as developed in British law, limited the discretion of the court to dismiss cases in three respects. First, the doctrine only applied where both of the parties to the suit were foreign. The doctrine also required that some other court in a "civilized" country have jurisdiction over the case. ${ }^{26}$ Finally, the burden of proving that the initial forum was so vexatious as to cause an actual hardship rested on the defendant. ${ }^{27}$ However, where these conditions were met, it rested in the discretion of the trial court to assess the appropriateness of the forum, with only the general guidance to "consider how best the ends of justice in the case in question and on the facts before it ... can be respectively ascertained and served." ${ }^{2 s}$

\section{Early applications of forum non conveniens in U.S. courts.}

While the phrase "forum non conveniens" rarely appears in the decisions of American courts prior to the publication of Paxton Blair's seminal article, The Doctrine of Forum Non Conveniens in AngloAmerican Law, ${ }^{29}$ in 1929, Blair and other scholars have noted a kindred assumption of discretion by both state and federal courts to decline jurisdiction in earlier cases. Many of the early cases in which U.S. courts declined jurisdiction arose in admiralty, where a party might obtain jurisdiction by the mere happenstance of a ship stopping at an

25 In Scotland, this would include English citizens, and vice versa. England only expanded the doctrine to protect English domiciliaries served at home with the House of Lords' decision in The Atlantic Star, [1974] A C 436.

26 See Gloag and Henderson, Law of Scotland at 22 (cited in note 22) ("For the success of the plea it is necessary to show that some other court, in a civilized country, has concurrent jurisdiction."), citing Clements, 4 Sess Cas (3d Ser) at 583 ("The defender does seem to have thought himself under an obligation to suggest what was the proper forum, but he unfortunately suggested one with no jurisdiction."). Compare the denial of the plea where the party failed to show that the other court had jurisdiction in Lynch $v$ Stewart, 9 Sess Cas (3d Ser) 860 (1871), cited in Gibb, International Jurisdiction at 227 (cited in note 22). It is not clear that the requirement of an alternative forum applied with the same force in England as in Scotland. See Paxton Blair, The Doctrine of Forum Non Conveniens in Anglo-American Law, 29 Colum L Rev 1, 33 (1929) (noting that although English courts did not require a showing that some other forum had jurisdiction over a claim before granting a forum non conveniens dismissal, Scottish courts "insisted upon" it).

27 See Gibb, International Jurisdiction at 212-13 (cited in note 22) (The court will not act unless "the party setting up the plea" shows "such hardship ... as would amount to vexatiousness or oppression if the court persisted in exercising jurisdiction. The inconvenience ... must amount to actual hardship, and this must be regarded as the sine qua non of success in putting forward a defence of forum non conveniens. For the general rule is that a court possessing jurisdiction must exercise it unless the reasons to the contrary are clear and cogent."). For an example of the failure to meet this burden, see Sim v Robinow, 19 Sess Cas (4th Ser) 665, 666 (1892) (rejecting a forum non conveniens motion to dismiss so that the claim could be brought in South Africa).

28 Société du Gaz, [1926] Sess Cas (H L) at 22.

2929 Colum L Rev 1 (cited in note 26). Blair only reports four cases using the phrase at the time of his article. Id at $2 \mathrm{n} 4$. 
American port. ${ }^{30}$ However, the prevalence of admiralty cases might be more a function of the higher incidence of foreign parties and distant events in admiralty than a restriction of discretion to admiralty. Moreover, application of the doctrine was not unique to admiralty. Several state courts employed similar discretionary dismissals in actions at law and equity.

Following the publication of Blair's article, forum non conveniens became an accepted doctrine of American common law. ${ }^{32}$ The Su-

30 See, for example, Mason $v$ The Ship Blaireau, 6 US (2 Cranch) 240, 264 (1804) (Marshall) (deciding to entertain a salvage case between a British ship and French ship after "weighing the considerations drawn from public convenience" and the fact that both parties consented to the suit); Willendson v Forsoket, $29 \mathrm{~F}$ Cas 1283, 1284 (D Pa 1801) ("It has been my general rule not to take cognizance of disputes between the masters and crews of foreign ships .... In some very peculiar cases, I have afforded the seamen assistance, to protect them against oppression and injustice; and in cases where the voyage was broken up, or ended here."); The Infanta, 13 F Cas 37, 39 (S D NY 1848) ("This court has repeatedly discountenanced actions by foreign seamen against foreign vessels not terminating their voyages at this port, as being calculated to embarrass commercial transactions and relations between this country and others in friendly relations with it."); The Maggie Hammond, 76 US (9 Wall) 435, 451-52 (1869) (stating that admiralty courts can refuse to take jurisdiction over a case where a remedy is sought by foreigners whose home courts would not give a remedy to American suitors); The Belgenland, 114 US 355, 363-68 (1885) (describing the circumstances in which it would be "inexpedient for the court to take jurisdiction" of a case arising from the collision of two foreign ships on the high seas, but holding that there is a strong presumption for exercising jurisdiction). See also Hobart Coffey, Jurisdiction Over Foreigners in Admiralty Courts, 13 Cal L Rev 93, 94 (1925) (surveying cases and concluding that while American admiralty courts have discretion not to assume jurisdiction, there is "no definite rule to be derived from the cases for the exercise of this discretion").

31 See, for example, Garner $v$ Thomas, 14 Johns 134, 136, 7 Am Dec 445 (NY 1817) (noting that in an assault and battery suit between two British subjects that allegedly occurred on a British ship, a New York court's "refusal to take cognizance of causes of actions for such torts may be justified by the manifest public inconvenience and injury which it would create to the community of both nations"); Johnson v Dalton, 1 Cow 543, 546, 13 Am Dec 564 (NY 1823) (explaining that courts may take jurisdiction in admiralty cases involving foreign parties but that courts "have exercised a sound discretion in entertaining jurisdiction or not, according to circumstances"); Great Western Railway Co v Miller, 19 Mich 305,315-16 (1869) (holding that even though the court had jurisdiction over a personal tort that occurred abroad between individuals who reside abroad, the inconvenience made it proper to decline further proceedings); Morrisette $v$ Canadian Pacific Railway Co, 76 Vt 267, 272-73, 56 A 1102, 1103 (1904) (holding that the court could have dismissed the case had a proper motion been made because of the availability of the Canadian forum); Collard $v$ Beach, 87 NYS 884, 885-86, 93 AD 339 (1904) (refusing jurisdiction in a tort case, where the injury occurred in another state and the parties resided in that state, because of the congestion of the court's calendar); Pietraroia $v$ New Jersey \& Hudson River Railway \& Ferry Co, 197 NY 434, 437, 91 NE 120, 121 (1910) (holding that it "is not to be doubted" that the Appellate Division had discretion to refuse to entertain jurisdiction of tort suit between nonresidents). For more citations, see Jacob J. Goldberg, Comment, 13 BU L Rev 349, 350-52 (1933) (citing earlier Massachusetts cases); Roscoe B. Gaither, Jurisdiction of Foreign Causes of Action, 66 US L Rev 303, 305-06 (1932) (citing earlier New York cases); Note, Suits Between Aliens in the Courts of This Country, 7 Am L Rev 417, 425-32 (1873) (discussing early American cases).

32 Barrett, 35 Cal L Rev at 388 (cited in note 13); Braucher, 60 Harv L Rev at $911-12$ (cited in note 13); and Brainerd Currie, Change of Venue and the Conflict of Laws, $22 \mathrm{U}$ Chi L Rev 405, 417 (1955), attribute the growth in the use of both the doctrine and the phrase in U.S. courts to Blair. 
preme Court's later admiralty cases used the term by name and suggested that the doctrine was not limited to admiralty. In the 1930s and 1940s, a series of Supreme Court cases made express though passing reference to the doctrine of forum non conveniens, ${ }^{34}$ culminating in the Court's exposition of the doctrine in Gulf Oil Corp $v$ Gilbert.

\section{B. The Modern Framework of Forum Non Conveniens Analysis}

Gilbert, the first Supreme Court case to endorse the use of forum non conveniens in a federal suit at common law, established the contours of modern forum non conveniens doctrine. In Gilbert, a plaintiff from Virginia brought suit in a New York federal district court against a defendant corporation organized in Pennsylvania and doing business in both Virginia and New York, alleging that negligent acts in Virginia resulted in a fire at the plaintiff's warehouse. ${ }^{36}$ The district court held jurisdiction and venue were proper. ${ }^{37}$ Nevertheless, the Supreme Court upheld the district court's dismissal of the suit in favor of the Virginia forum under forum non conveniens.

As a threshold matter, the Court noted that the doctrine of forum non conveniens "presupposes at least two forums in which the defendant is amenable to process" and serves to provide "criteria for the choice between them." ${ }^{38}$ Moreover, the Court recognized that the

33 See Canadian Malting Co v Paterson Steamships, Ltd, 285 US 413, 423 \& n 6 (1932) (noting Blair's article and recognizing that on occasion courts in law and equity also decline to exercise jurisdiction "in the interest of justice"); Langnes v Green, 282 US 531,544 (1931) (noting that admiralty cases are just an example of the fact that American courts have discretion as to whether they will entertain suits between nonresident foreigners).

34 See Canadian Malting Co,285 US at 423 ("Courts of equity and of law also occasionally decline ... to exercise jurisdiction, where the suit is between aliens or where for kindred reasons the litigation can more appropriately be conducted in a foreign tribunal."); Broderick $v$ Rosner, 294 US 629, 642-43 (1935) ("A State ... may in appropriate cases apply the doctrine of forum non conveniens."); Baltimore \& Ohio Railroad v Kepner, 314 US 44, 55 (1941) (Frankfurter dissenting) (noting that the majority opinion does not "question the familiar doctrine of forum non conveniens"); Williams v Green Bay \& Western Railroad, 326 US 549 (1946) (finding forum non conveniens inappropriate for the case without questioning the validity of the doctrine). At the same time, the Court was also expanding judicial discretion in the area of abstention, holding that a federal court could abstain from exercising jurisdiction in order to allow a state court to decide important state law questions. See Railroad Commission v Pullman Co, 312 US 496, 501 (1941) (holding that federal courts can abstain from a civil rights issue until the state gives definitive construction to its statute); Buford v Sun Oil Co, 319 US 315, 326-34 (1943) (holding that a federal court can abstain from exercising jurisdiction over a Texas oil well dispute because of Texas's interests in the conservation and regulation issues involved).

35330 US 501 (1947). See also its companion case, Koster v (American) Lumbermens Mutual Casualty $C o, 330$ US 518, 521-22, 524-26 (1947) (considering problems peculiar to applying forum non conveniens in the context of derivative actions).

36330 US at 502-03.

37 Id at 504.

38 Id at $506-07$. 
complexity of assessing the relative convenience of two fora resists reduction to dispositive rules. Instead, the Court attempted to guide the trial court's exercise of discretion by delineating an array of factors that a trial court should weigh when considering the appropriateness of a particular forum. The primary factors the Court suggests gauge the "private interests" of the litigants. ${ }^{40}$ In this balancing of private interests, the court ought to disturb the plaintiff's choice of forum only where the balance is strongly in favor of the defendant. ${ }^{41}$ Additionally, the trial court might consider factors of "public interest" to ensure that the public is not burdened by the time and expense of a trial "which has no relation" to the community hosting it. ${ }^{42}$ By allowing the trial court to balance the interests of the parties and the forum, the Supreme Court sought to direct the discretion of the trial court, while still allowing the trial court the flexibility to resist undue forum shopping and harassment of defendants.

Since the Court's holding in Gilbert, shifting judicial and legislative contexts have restricted the applicability of forum non conveniens, though the general outlines of the current doctrine remain in accord with Gilbert. In 1948, Congress passed an omnibus bill overhauling Title 28 of the U.S. Code, which governs the judiciary and judicial procedure. As a part of that overhaul, Congress enacted a venuetransfer statute, Section 1404(a). The enactment of the transfer stat-

39 Id at 508 (noting that courts have not defined, and probably cannot define, all the circumstances under which a forum non conveniens dismissal would be appropriate).

40 Id ("Important considerations are the relative ease of access to sources of proof; availability of compulsory process for attendance of unwilling, and the costs of obtaining attendance of willing, witnesses; possibility of view of premises, if view would be appropriate to the action; and all other practical problems that make trial of a case easy, expeditious and inexpensive. There may also be questions as to the enforceability of a judgment if one is obtained. The court will weigh relative advantages and obstacles to fair trial.").

41 Id ("[U]nless the balance is strongly in favor of the defendant, the plaintiff's choice of forum should rarely be disturbed.").

42 Id at 508-09 (listing public interest factors such as the administrative difficulties of congested courts; burdening citizens with jury duty in a community with no relation to the matter at issue; an interest in having courts apply their own law and avoiding difficult questions of conflicts of law; and the "local interest in having localized controversies decided at home").

43 Id at 507 ("Many of the states have met misuse of venue by investing courts with a discretion to change the place of trial on various grounds, such as the convenience of the witnesses and the ends of justice."), citing Foster, 44 Harv L Rev at 47, 82 (cited in note 14).

44 Act of June 25, 1948, Pub L No 773, ch 646, § 1404(a), 62 Stat 869, 937, codified at 28 USC $\$ 1404$ (a) (1994) ("For the convenience of parties and witnesses, in the interests of justice, a district court may transfer any civil action to any other district or division where it might have been brought."). This provision was modeled on the doctrine of forum non conveniens. However, as construed, the statute differs from the doctrine in a number of ways. First, the moving party faces a lesser burden in demonstrating extreme inconvenience because the transfer is less harmful to the plaintiff than a forum non conveniens dismissal. See Norwood v Kirkpatrick, 349 US 29, 32 (1955) (holding that Congress intended courts' discretion to be broader under $\$ 1404$ (a) than under forum non conveniens). Second, in light of the language of the statute, a case could only be transferred to a forum where the plaintiff could have brought the suit in the 
ute had a dramatic impact on forum non conveniens, limiting its scope in federal court to cases involving dismissal to a foreign forum, since the new domestic transfer statute would otherwise apply.

In addition, developments in due process limitations on personal jurisdiction provide further protection for some potential defendants from being haled into an inconvenient forum. Where personal jurisdiction over the defendant does not rest on physical presence in the forum, the "minimum contacts" test affords potential defendants some protection against facing litigation in a wholly inconvenient forum by analyzing the relationship among the defendant, the forum, and the litigation to determine personal jurisdiction. These jurisdictional developments reduce the number of cases in which forum non conveniens remains applicable. ${ }^{45}$

Finally, in Piper Aircraft Co $v$ Reyno, ${ }^{46}$ the Supreme Court considered two unanswered questions: the weight to be given to changes in substantive law and the relevance of the plaintiff's residence. The plaintiffs in Piper brought a wrongful death action against the American companies responsible for the construction of a plane that crashed in Scotland, killing Scottish passengers. ${ }^{47}$ The district court dismissed in favor of a Scottish forum. First, the Supreme Court considered the weight to be given to the impact that dismissal would have on the substantive law to be applied, holding that " $[t]$ he possibility of a change in substantive law should ordinarily not be given conclusive or even substantial weight in the forum non conveniens inquiry," ${ }^{, 48}$ lest the doc-

first place-the defendant cannot consent to jurisdiction in the transferee court. See Hoffman v Blaski, 363 US 335, 344 (1960) (holding that a district court may not transfer a case to a forum where a plaintiff could not originally bring the claim, even if the defendant consents). Finally, the transferee court is obligated to apply the same law that the transferor court would have, protecting the plaintiff from unfavorable changes in law. See Van Dusen v Barrack, 376 US 612, 639 (1964) ("[W] here the defendants seek transfer, the transferee district court must be obligated to apply the state law that would have been applied if there had been no change in venue.").

45 See Marc O. Wolinsky, Comment, Forum Non Conveniens and American Plaintiffs in the Federal Courts, 47 U Chi L Rev 373, 377-78 (1980) (noting how the minimum contacts doctrine "reduce[s] severely the number of cases in which forum non conveniens might be considered"). The incorporation of contact and convenience factors into the due process limits on personal jurisdiction, see International Shoe Co $v$ Washington, 326 US 310,316 (1945) (finding that due process requires "certain minimum contacts" with the forum asserting jurisdiction), and Shaffer $v$ Heitner, 433 US 186, 208-10 (1977) (finding that property only creates jurisdiction if it is related to the plaintiff's cause of action), reduces the likelihood of inconvenience sufficient to require a forum non conveniens dismissal in those cases where the defendant is not present in the immediate forum. However, the protection afforded by these cases is limited to assertions of personal jurisdiction against absent defendants. In Burnham v Superior Court of California, 495 US 604, $610,621-22$ (1990), the Supreme Court reaffirmed the viability of personal jurisdiction based solely on physical presence.

46454 US 235 (1981).

47 Id at 238-39.

48 Id at 247. 
trine become "virtually useless." whether a foreign plaintiff's choice of forum deserved the same level of deference as a domestic plaintiff's and held that "a foreign plaintiff's choice [of forum] deserves less deference" ${ }^{\text {s0 }}$ because the foreign plaintiff's choice is less likely to be convenient for the defendant. In an historical irony, the Court sent the case back to Scotland on a forum non conveniens dismissal. ${ }^{\text {st }}$

Piper also recognized a concern underlying the application of forum non conveniens - the fear that American courts will attract foreign plaintiffs prosecuting suits that have no connection with the United States and may not even involve American defendants. ${ }^{52}$ The discretion to decline to hear suits brought unreasonably by plaintiffs holds particular relevance in the contemporary American context. For both substantive and procedural reasons, American courts are particularly attractive to foreign plaintiffs. ${ }^{53}$ Insofar as U.S. courts are compelled to entertain these suits, American businesses might bear the brunt of these suits and thus a disproportionate share of liability relative to similarly situated businesses not amenable to process in the United States. Forum non conveniens can serve to insulate American industry and courts (at least partially) from the extra costs imposed by American law.

\section{The Use of Conditions on Forum Non Conveniens Dismissals}

Since the Supreme Court's affirmance of the doctrine of forum non conveniens in Gilbert, federal courts have increasingly turned to forum non conveniens as a tool for managing their dockets, particularly in cases brought by foreign plaintiffs. Accompanying this increase in forum non conveniens dismissals has been a concomitant increase in the imposition of conditions on dismissals. The treatment of such conditions in district and appellate court opinions, however, makes it difficult to analyze the use of conditions, as they are typically ap-

49 Id at 250.

50 Id at 255-56, citing Wolinsky, $47 \mathrm{U}$ Chi L Rev at 382-83 (cited in note 45).

51454 US at 261.

52 Id at 251-52. Such concerns are not new. See Blair, 29 Colum $L$ Rev at 1 (cited in note 26).

53 See Miller, $58 \mathrm{U}$ Chi L Rev at 1369 (cited in note 4) ("[P]ro-plaintiff tort laws, discovery rules, choice of law rules, contingent fee arrangements, and jury awards continue to attract foreign plaintiffs to U.S. forums."). See also Piper, 454 US at 252 n 18 (stating that the presence of strict liability, malleable choice-of-law rules, jury trials, contingent attorney's fees, and extensive discovery proceedings attract foreigners to U.S. courts); Russell J. Weintraub, $A$ Proposed Choice-of-Law Standard for International Products Liability Disputes, 16 Brooklyn J Intl L 225, 225-26 (1990) ("The chances are excellent ... that the combination of favorable tort law and favorable conflicts law will remain a significant [attraction to foreign plaintiffs]."); Note, Foreign Plaintiffs and Forum Non Conveniens: Going Beyond Reyno, 64 Tex L Rev 193, 196-204 (1985) (describing attractive features of the U.S. legal system). Consider also note 4. 
pended to decisions without explanation, analysis, or justification. These conditions can be divided productively into two categoriesthose that ensure the availability of the alternate forum and those that compensate the plaintiff for lost conveniences.

\section{Types of conditions.}

a) Conditions to ensure the availability of the alternate forum. By far the most prevalent conditions placed upon forum non conveniens dismissals are conditions that effectively ensure that the alternative forum proffered by the defendant is in fact available to the plaintiff without great risks or the effective foreclosure of her case. Perhaps the most basic of these is a requirement that the suggested alternate forum actually accept jurisdiction over the case. ${ }^{55}$ In a similar vein is the condition that the defendant consent to personal jurisdiction in the alternate forum and in fact appear for trial. ${ }^{\text {s6 }}$ The source of this common condition is the recognition that if the plaintiff cannot obtain jurisdiction over the defendant in the proposed alternate forum, that forum is at best only nominally available to her.

Many courts also require defendants to waive any statute of limitations defenses in the alternate forum that may have accrued since the plaintiff filed the case in its initial forum." While not technically

54 See, for example, In re Union Carbide Corp Gas Plant Disaster at Bhopal, India, $634 \mathrm{~F}$ Supp 842, 867 (S D NY 1986), affd in part, modified in part, 809 F2d 195 (2d Cir 1987); Interpane Coatings, Inc v Australia and New Zealand Banking Group Ltd, 732 F Supp 909, 918 (N D Ill 1990) (conditioning dismissal on defendant waiving the statute of limitations and accepting the foreign court's jurisdiction).

55 This condition was used in El-Fadl $v$ Central Bank of Jordan, 75 F3d 668, 679 (DC Cir 1996); Mercier v Sheraton International, Inc, 981 F2d 1345, 1350 (1st Cir 1992). For a more comprehensive listing, see Tim A. Thomas, Annotation, Validity and Propriety of Conditions Imposed Upon Proceedings in Foreign Forum by Federal Court in Dismissing Action Under Forum Non Conveniens, 89 ALR Fed 238, \$ 4(g) (1988 \& Supp 1998).

56 See $\mathrm{El}$-Fadl, $75 \mathrm{F3d}$ at 679 (allowing dismissal on condition of party accepting jurisdiction of Jordan); Mercier, 981 F2d at 1350 (upholding dismissal conditioned on submission to Turkish courts); Quintero v Klaveness Ship Lines, 914 F2d 717, 731 (5th Cir 1990); In re Union Carbide Corp Gas Plant Disaster, 809 F2d 195, 203 (2d Cir 1987); Constructora Spilimerg, C A v Mitsubishi Aircraft Co, 700 F2d 225, 226 (5th Cir 1983); Pain v United Technologies Corp, 637 F2d 775, 785 (DC Cir 1980); Dahl v United Technologies Corp, 632 F2d 1027, 1029 (3d Cir 1980); Garis v Compania Maritima San Basilio, 386 F2d 155, 157 (2d Cir 1967) (upholding discretionary refusal to take jurisdiction conditioned on defendant's submission to jurisdiction in the Greek courts and appearance in any action instituted by plaintiff in Greece). See also Thomas, Annotation, 89 ALR Fed at $238 \$ 4$ (a) (cited in note 55) (citing cases).

57 See Sussman v Bank of Israel, 990 F2d 71,71 (2d Cir 1993); Mercier, 981 F2d at 1352 n 6 (conditioning dismissal on waiver of statute of limitations defense); Quintero, 914 F2d at 731; Union Carbide, 809 F2d at 203-04; Pain, 637 F2d at 785. See also Thomas, Annotation, 89 ALR Fed at $238 \S 4$ (c) (cited in note 55) (listing cases where dismissals were conditioned on the waiving of statute of limitations defenses). This reasoning has also been extended to the related defense of laches. See Fajardo v Tidewater, Inc, 707 F2d 858, 862 (5th Cir 1983). See also Thomas, Annotation, 89 ALR Fed at 238 \& 4(h). 
ensuring the actual availability of the alternate forum, such a requirement serves to protect the practical as well as theoretical availability of the forum for the plaintiff's claims. On rare occasions, some courts will also take more extreme steps to ensure that the alternate forum is in practice available to the plaintiff. For instance, one court conditioned forum non conveniens dismissal on an "undertaking," or promise, by appropriate officials of the state of the alternate forum that the plaintiff would not be detained in connection with another pending suit were he to travel there to initiate his suit.

One final condition that courts employ to secure the practical availability of the proposed alternate forum is that the defendant consent to the enforceability of any final judgment by U.S. courts, or even post bonds as security to compensate for lost attachments." While again not technically related to the availability of the forum, these conditions reflect recognition by the courts that a suit in a forum that would yield an unenforceable judgment is in practice indistinguishable from no suit at all. Moreover, given the necessary contention by the defendant that the proposed forum is adequate, finding such a defendant estopped from contesting any adverse judgment from that forum appears reasonable. ${ }^{60}$

b) Conditions to compensate the plaintiff for undue inconvenience of dismissal. Occasionally, federal courts impose conditions not only to ensure the availability of an alternate forum, but also to compensate the plaintiff for the loss of convenience caused by dismissal. Of these uncommon conditions, the most frequent are conditions requiring a commitment to make witnesses and other evidence available to the plaintiff in the alternate forum. ${ }^{61}$ Such conditions assure the plaintiff access to evidence that might otherwise be beyond the compulsory power of the alternate forum. Such evidentiary conditions have also included a commitment from the defendant to make witnesses avail-

58 Sussman, 990 F2d at $71-72$.

59 See Mercier, $981 \mathrm{~F} 2 \mathrm{~d}$ at 1349 (requiring defendant's commitment to satisfy foreign court's judgment); Quintero, 914 F2d at 731 (same); Constructora Spilimerg, 700 F2d at 226 (same); Garis, $386 \mathrm{~F} 2 \mathrm{~d}$ at 157 (requiring defendant to post bond to guarantee appearance and payment of any judgment). See also Thomas, Annotation, 89 ALR Fed at $238 \S 4$ (d) and (f) (cited in note 55). But compare Union Carbide, $809 \mathrm{~F} 2 \mathrm{~d}$ at 204 (rejecting requirement in light of New York statute providing terms for the enforceability of foreign judgments).

60 Civil judgments from foreign courts are typically enforceable in U.S. courts in any case so long as minimal due process requirements are met. See Hilton $v$ Guyot, 159 US 113, 227-28 (1895) (holding that foreign judgments are prima facie evidence of the resolution of the dispute).

61 In Piper, the Supreme Court suggested in dicta that district courts can condition dismissal on a defendant's agreement to provide all relevant records. 454 US at $257 \mathrm{n} 25$. See, for example, Mercier, $981 \mathrm{~F} 2 \mathrm{~d}$ at 1353 (upholding condition of making witnesses and records available); Quintero, $914 \mathrm{~F} 2 \mathrm{~d}$ at 731 (same); Ali v Offshore Co, $753 \mathrm{~F} 2 \mathrm{~d} 1327,1334 \mathrm{n} 16$ (5th Cir 1985) (same). See also Thomas, Annotation, 89 ALR Fed at $238 \S 4$ (e) (cited in note 55) (citing cases). 
able in the United States for deposition, ${ }^{62}$ a direction to have necessary evidentiary documents translated, ${ }^{63}$ and an agreement not to protest the admissibility of evidence already in the United States. However, two circuits have rejected conditions requiring defendants either to consent to discovery under the Federal Rules of Civil Procedure, ${ }^{65}$ or to "facilitate discovery" in the foreign forum. ${ }^{66}$

In particular circumstances, other compensatory conditions have been considered. One case rejected the requirement that defendant waive a "cost-bond" that the plaintiff would have had to put up in order to initiate suit in the foreign forum. ${ }^{67}$ Another case on behalf of intervenors required that the initial plaintiff cooperate with the intervenors in the appointment of a new trustee to represent their joint interests in a bankruptcy case, and conditioned the dismissal on the trustee's actual pursuit of the intervenors' claim. ${ }^{68}$ By far the most dramatic condition imposed on defendants has been the requirement that they not contest liability in the foreign forum. ${ }^{69}$ Such a condition more than compensates the plaintiff for any inconvenience suffered as a consequence of the change in forum.

\section{Appellate review of conditions.}

The appellate review of conditions, as opposed to the dismissal itself, is relatively rare. ${ }^{70}$ Where reviewed, the conditions, like the dismissal itself, are typically treated as discretionary actions committed to the judgment of the trial court, and thus subject to an "abuse of discretion" standard of review. "Unfortunately, there is no settled judgment

62 See Sherkat Tazamoni Auto Internash v Hellenic Lines, Ltd, 277 F Supp 462, 464 (S D NY 1967) (conditioning dismissal on the deposition of a witness in New York).

63 See Dahl, 632 F2d at 1031 (suggesting that district court amend its dismissal order to "explicitly place the burden of translation" on the defendant).

64 See Garis, 386 F2d at 157.

65 See Union Carbide, 809 F2d at 205 (concluding that Indian discovery rules and not the Federal Rules of Civil Procedure should control discovery).

66 See Mercier, 981 F2d at 1352-53 (holding that foreign forum need not use discovery procedures identical to or as "generous" as American ones).

67 Id at 1353. See also text accompanying notes 76-79.

68 Blanco v Banco Industrial de Venezuela, 997 F2d 974, 983-84 (2d Cir 1993) (observing that "forum non conveniens dismissals are often appropriately conditioned to protect the party opposing dismissal").

69 See Pain, 637 F2d at 785 (upholding district court order requiring defendant not to contest liability but rather to proceed directly to trial on the damages issue "as the price for permitting" forum non conveniens dismissal); Chhawchharia v Boeing Co, 657 F Supp 1157, 1163 (S D NY 1987) (directing defendant not to contest liability if the foreign forum rejected its defense of release).

70 For some of the few examples, see Mercier, 981 F2d 1345; Union Carbide, 809 F2d 195; Pain, 637 F2d 775. The Supreme Court has not addressed the use of conditions. While the dismissal in Piper depended on the defendants' consent to personal jurisdiction in the alternate forum, the Court noted, but did not discuss, this fact. Piper, 454 US at 242.

71 See Mercier, 981 F2d at 1349 (reviewing under "clear abuse of discretion" standard); 
on what constitutes abuse of discretion in conditioning forum non conveniens dismissals.

In In re Union Carbide Corp Gas Plant Disaster, ${ }^{n}$ the Second Circuit rejected two conditions placed on the dismissal by the trial court. First, after upholding a condition requiring consent to personal jurisdiction and waiver of the statue of limitations, the court found the condition that defendants consent to the enforceability of any Indian judgment in error, as it was based on an "erroneous legal assumption" that such a judgment would otherwise be unenforceable in U.S. courts. ${ }^{3}$ The court further noted that the impact of the court order was "ambiguous" given the due process requirements of the existing New York enforcement statute. ${ }^{74}$ Second, the court held a condition requiring the defendant to consent to broad discovery under the Federal Rules of Civil Procedure violated principles of equal treatment when the court did not have the power to impose a parallel condition on the plaintiff. ${ }^{75}$ However, though the Union Carbide court overruled the imposition of these two conditions, it suggested no principle or standard upon which it assessed the conditions, and instead made judgments tied to the particular facts of the case.

Similarly, the First Circuit in Mercier $v$ Sheraton International, Inc ${ }^{76}$ upheld the conditions imposed by the district court but rejected two conditions proposed by plaintiffs on appeal, both of which "contemplate[d], in effect, that Turkish procedure be brought more in line with the procedures utilized in American courts." First, the court rejected a proposal that the defendant be required to "facilitate discovery," arguing that differences in procedure do not make an alternate forum inadequate. ${ }^{78}$ Second, the court rejected a condition that the defendant waive a Turkish requirement that plaintiffs post a cost-bond to cover the defendant's legal fees if they lose the case, arguing that the district court did not abuse its discretion in ruling that the burden presented by the cost-bond did not rise to such a level as to render the forum inadequate or unavailable. The First Circuit's rejection of the

Union Carbide, 809 F2d at 202 (noting that trial courts receive deference in forum non conveniens determinations); Pain, 637 F2d at 781. Insofar as the weighing of factors in the basic forum non conveniens context is subject to such a standard of review, see Piper, 454 US at 257, the use of the same standard in reviewing conditions seems appropriate, as the imposition of conditions presumably involves assessments that are similar in complexity to those that have already been committed to the sound discretion of the trial court.

72809 F2d 195 (2d Cir 1987).

73 Id at 204-05.

74 Id.

75 Id at 205.

76981 F2d 1345 (1st Cir 1992).

77 Id at 1352.

78 Id at 1352-53.

79 Id at 1353. 
plaintiff's proposals reflected both a consideration of the facts of the case and a concern about intruding on the procedures of a foreign court. Like the Second Circuit, however, the First Circuit presented no standard under which a court ought to judge the appropriateness of specific conditions.

Finally, in Pain v United Technologies Corp ${ }^{\text {so }}$ the D.C. Circuit upheld three conditions imposed by the district court. ${ }^{81}$ In assessing the requirements that the defendant consent to jurisdiction and waive statute of limitations defenses, the court found that the trial court's design to "secure adequate alternative forums" for the plaintiffs to pursue their actions was not an abuse of discretion. ${ }^{82}$ More significantly, the court found that a condition directing the defendant not to contest liability in the foreign forum, and instead to proceed directly to the question of damages, was a "concession from [the defendant] as the price for permitting it to shift the case from plaintiffs' chosen forum" and was not an abuse of discretion. In doing so, the court implicitly recognized that it was an equitable use of discretion to condition dismissals in order to protect plaintiffs' positions. The court failed, however, to articulate the principles on which it based its determinations.

\section{Potential GUIDING PRINCIPLES FOR THE USE OF CONDITIONS}

In light of the increased use of conditional forum non conveniens dismissals, the lack of any principles guiding the discretion of trial courts in placing such conditions is a considerable lacuna. The cases imposing conditions upon forum non conveniens dismissals themselves yield little upon which to construct limiting principles for such impositions. An effort to find guiding principles, then, must begin with a consideration of possible sources for that guidance. This Part addresses two potential sources for such guiding principles-institutional concerns surrounding the doctrine and the historical foundations of the doctrine.

$80 \quad 637$ F2d 775 (DC Cir 1980).

81 Id at 785 .

82 Id.

83 Id.

84 The focus on these two alternatives is not meant to suggest that they are the only plausible candidates. In offering these possibilities, my purpose is not to exclude competing candidates but rather to suggest a starting point for generating and assessing promising guiding principles for the use of conditions. Though other sources might be fruitful for these purposes, they are beyond the scope of this Comment. 


\section{A. Institutional Concerns as Potential Source}

The doctrine of forum non conveniens is founded in judicial discretion, without express statutory authorization. ${ }^{-s 5}$ As such, it arises under peculiar institutional circumstances and raises questions about the appropriate allocation of institutional authority between the judiciary and the legislature. As the application of forum non conveniens takes place at a point of tension between judicial discretion and legislative control, these institutional concerns might inform efforts to guide the discretion of trial courts to condition forum non conveniens dismissals.

1. The allocation of institutional authority.

a) Judicial discretion. The doctrine of forum non conveniens rests on the notion that courts are peculiarly competent to engage in the complex weighing of factors that the doctrine entails. While the suits in which it might apply have already been culled by statutory rules imposing subject matter jurisdiction limits, constraints on personal jurisdiction, and venue requirements, the doctrine assumes that these rules are overinclusive." As Justice Jackson noted in Gilbert, "These statutes are drawn with a necessary generality .... But the open door

85 Born notes this lack of statutory (and even constitutional) authority for the doctrine of forum non conveniens. See Born, International Civil Litigation at 285 (cited in note 4).

86 The formal source of courts' authority to issue forum non conveniens dismissals is most likely judicially crafted federal procedural common law either founded on the inherent "judicial power" vested in Federal courts by Article III of the Constitution, US Const Art III, § 1, or perhaps implicitly authorized by federal statutes governing the judiciary. However, beyond the recognition that the current doctrine remains a judicially crafted doctrine calling for the exercise of judicial discretion, the precise technical details of its formal source are beyond the scope of the argument here. In any case, the relationship of forum non conveniens to federal common law is a subject worthy of its own full comment and could not be addressed adequately here. For an early effort, see Note, Recent Cases, 14 U Chi L Rev 97, 99-102 (1946) (arguing that the federal common law of forum non conveniens, and not state law, ought to apply in diversity suits).

87 By contrast, opponents of forum non conveniens have argued that, because of the obstacles the suit must clear before the court gets to forum non conveniens, the doctrine is redundant, or at best, the issues it deals with would be more appropriately addressed by other mechanisms. A prospective plaintiff must clear several hurdles before the issue of forum non conveniens becomes relevant. First, the trial court must have subject matter jurisdiction over the plaintiff's complaint, a prerequisite that protects, in some respects, the court from entertaining suits that do not hold some interest for the forum. Second, the trial court must have personal jurisdiction over the defendant, and this requirement safeguards the defendant from being unfairly haled into a distant, unrelated forum. Finally, the suit must meet the court's venue requirements, ensuring that there is at least some appropriateness to the forum. See Allan R. Stein, Forum Non Conveniens and the Redundancy of Court-Access Doctrine, 133 U Pa L Rev 781, 841 (1985) (urging decreased reliance on forum non conveniens because it resolves policy questions in an arbitrary and inconsistent fashion). See also Margaret G. Stewart, Forum Non Conveniens: $A$ Doctrine in Search of a Role, $74 \mathrm{Cal} \mathrm{L}$ Rev 1259, 1263 (1986) ("When the jurisdictional inquiries are conducted properly, it becomes clear that the doctrine of forum non conveniens has outlived its usefulness."). 
may admit those who seek not simply justice but perhaps justice blended with some harassment." might be intentional-legislatures may deem it more harmful to deny court access to potentially meritorious suits than to bear the costs of eliminating undeserving suits at a later stage. Moreover, the type of analysis necessary to identify the meritorious and undeserving claims at this stage might be ideally suited to judicial discretion.

In fact, making these sorts of determinations may fit squarely within the tradition of judicial discretion. Professor Blair asserts that one of the advantages of forum non conveniens as a device to combat congestion in the courts is that its benefits can be gained without any new legislation; rather, the doctrine merely involves "an appeal to the inherent powers possessed by every court of justice ... which are incontestably necessary to the effective performance of judicial functions. ${ }^{, 99}$ Judicial discretion is not only an essential judicial tool, but also one with a respectable historical pedigree. ${ }^{\circ}$ Given the complex and highly fact-specific nature of the considerations that go into forum non conveniens decisions, this analysis might be ill-suited to the mechanical and somewhat rigid rules of jurisdiction and venue. Instead, it may be ideally suited to discretionary resolution by trial judges who can weigh the unique characteristics of cases and arrive at appropriate outcomes."

b) Legislative control. Advocates of legislative control of jurisdiction raise two objections to this argument for judicial discretion: (1) the power of courts is constrained by the statutes that authorize it, and (2) where discretion is appropriate, Congress is competent to authorize it by statute. ${ }^{2}$ Federal courts can entertain a suit only through the

88330 US at 507.

89 Blair, 29 Colum L Rev at 1 (cited in note 26).

90 See David L. Shapiro, Jurisdiction and Discretion, 60 NYU L Rev 543 (1985). Shapiro argues that "the existence of this discretion [in matters of jurisdiction] is much more pervasive than is generally realized, and that it has ancient and honorable roots at common law as well as in equity," and that its continued exercise "has much to contribute to the easing of interbranch and intergovernmental tensions in our complex system of government." Id at 545. For a general discussion, see Renzo D. Bowers, The Judicial Discretion of Trial Courts (Bobbs-Merrill 1931); Nathan Isaacs, The Limits of Judicial Discretion, 32 Yale L J 339 (1923).

91 On the resistance of these issues to resolution by general rules, see Gilbert, 330 US at 508 ("Wisely, it has not been attempted to catalogue the circumstances which will justify or require either grant or denial of [forum non conveniens] remedy. The doctrine leaves much to the discretion of the court to which the plaintiff resorts, and experience has not shown a judicial tendency to renounce one's own jurisdiction so strong as to result in many abuses."); Dainow, 29 Ill L Rev at 869 (cited in note 13) ("While some general rules may be enunciated for all courts, the core of the matter is that each particular arrangement of facts must be considered as a separate and independent question .... [A]nd the question of exercising jurisdiction should be left [ ] largely to the discretion of the court.").

92 For parallel arguments in the context of abstention, see Martin H. Redish, Abstention, Separation of Powers, and the Limits of the Judicial Function, 94 Yale L J 71 (1984) (arguing that 
empowerment of jurisdictional statutes, and on several occasions the Supreme Court has expressed in dicta an understanding that where a federal court has jurisdiction, it is obligated to exercise it. ${ }^{93}$ These assertions, however, are not in the context of forum non conveniens, and the other practices of courts belie such an absolute claim."

At stake is the ability of the Congress to control the jurisdiction of the federal courts through statute. This concern for legislative control of jurisdiction provides the basis of Justice Black's dissent in Gilbert, where he argued that the desirability of federal trial courts exercising discretion at common law presents "questions of policy which Congress should decide." 96 The error in the argument for judicial discretion is not that it is wrong, but that it does not prove enough - it must also answer why courts should exercise discretion in the absence of congressional authorization to do so.

This argument gains traction in the context of the passage of Section 1404(a). First, its passage demonstrates that Congress is competent and willing to act effectively in such jurisdictional arenas. More fundamentally, the enactment of Section 1404(a) raised some questions about the continuing viability of forum non conveniens. According to the Reviser's Note, the section was drafted "in accordance

all forms of judge-made abstention doctrines are illegitimate).

93 For instance, in Cohens $v$ Virginia, 19 US (6 Wheat) 264 (1821), Chief Justice Marshall remarked in an oft-quoted phrase that "[w]e have no more right to decline the exercise of jurisdiction which is given, than to usurp that which is not given. The one or the other would be treason to the constitution." Id at 404. More recently, Justice Brennan observed that the federal courts have a "virtually unflagging obligation ... to exercise the jurisdiction given them." Moses H. Cone Memorial Hospital v Mercury Construction Corp, 460 US 1, 15 (1983), quoting Colorado River Water Conservation District v United States, 424 US 800, 817 (1976) (ironically declining jurisdiction). This tendency likely evolved from the common law rule Judex tenetur impertiri judicium suum: a judge must exercise jurisdiction in every case in which he is seized of it. See Gibb, International Law of Jurisdiction at 212-13 (cited in note 22) ("[T] he general rule is that a court possessing jurisdiction must exercise it unless the reasons to the contrary are clear and cogent."). See also McClellan v Carland, 217 US 268, 282 (1910) (holding that a federal court with proper jurisdiction cannot turn a case over to a state with concurrent jurisdiction at the state's request); Ex parte Young, 209 US 123, 142-43 (1908) (citing Marshall's opinion in Cohen); Hyde v Stone, 61 US (20 How) 170, 175 (1857) ("[T]he courts of the United States are bound to proceed to judgment ... in every case to which their jurisdiction extends.").

94 See, for example, the doctrine of abstention, discussed in note 34.

95 For a discussion of the American tendency to regulate jurisdiction through statute rather than by common law, see Foster, 44 Harv L Rev at 46 (cited in note 14) (noting the American tendency to regulate venue by statutes that are more restrictive of plaintiff's choice of venue than the common law). Note that the claim that judicial discretion threatens the ability of Congress to regulate jurisdiction assumes that discretion is not implicit in existing jurisdictional statutes.

96330 US at 515.

97 One might respond that process failures prevent legislative consideration of such a matter, especially given the small number of cases at stake, see Foster, 44 Harv L Rev at 52 (cited in note 14) (calling "legislative inertia" an almost insurmountable obstacle), though the passage of Section 1404(a) might belie such a claim. 
with the doctrine of forum non conveniens,", ${ }^{, 98}$ and was intended as a revision of the common law, not merely a declaration of it." While Section 1404(a) only addresses domestic transfers, it represents an assertion of congressional authority that ought to temper further judicial action in the area. ${ }^{100}$ The open question is why courts should act on discretion where the legislature is apparently competent to act. ${ }^{101}$

\section{Institutional concerns and limiting discretion to condition} forum non conveniens dismissals.

These institutional concerns present a potential basis for limiting the discretion of trial courts to condition forum non conveniens dismissals. First, insofar as courts issuing forum non conveniens dismissals are doing so without express legislative warrant, perhaps the practice should be employed as narrowly as possible against a presumption of compulsory jurisdiction. Second, given the congressional attention to the issue of appropriate venue with the passage of the venuetransfer statute, perhaps courts should deploy conditions to render the practice of international forum non conveniens dismissals as analogous as possible to congressionally approved federal venue transfers. These possibilities will be considered in turn.

a) Mandatory jurisdiction as background principle. The jurisdiction of the lower federal courts (and arguably the appellate jurisdiction of the Supreme Court) requires not only a basis in the Constitution but also congressional authorization. If the statutory empowerment of the courts to hear certain cases does not create an obligation to do so, ${ }^{102}$ perhaps a presumption of mandatory jurisdiction can serve as a background rule against which deviations from it should be narrowly construed. Thus the impetus to constrict the discretion of trial courts to deviate from legislative conferral of jurisdiction might serve as a delimiting principle for the imposition of conditions on forum non conveniens dismissals.

98 Reviser's Note, HR Rep No 80-308, 80th Cong, 1st Sess, A132 (1947).

99 Norwood v Kirkpatrick, 349 US 29, 32 (1955) (holding that in enacting Section 1404(a), Congress intended to lower the showing of inconvenience needed, relative to the common law).

100 In fact, at least one commentator argued that the decision in Gilbert ought to be regarded "as an unsound aberration which had to be, and was, corrected by congressional action which at the time provided a better solution for the underlying problem." Currie, $22 \mathrm{U}$ Chi $\mathrm{L}$ Rev at 436 (cited in note 32 ).

101 In this respect, the issue is similar to the Court's "dormant" Commerce Clause decisions that strike down state statutes without Congressional warrant, where arguably Congress retains the resources to protect its powers without the courts' sua sponte assistance.

102 Whether or not it should create such an obligation, the current practice of federal trial courts indicates it clearly does not, in light of such doctrines as forum non conveniens and abstention. For a general discussion, see Shapiro, 60 NYU L Rev 543 (cited in note 90). 
Unfortunately, even accepting the argument that discretionary departures from statutorily conferred jurisdiction should be stringently narrowed in light of their exceptional character, it is not clear how this affects conditioning forum non conveniens dismissals. The initial reaction is to presume that narrowing the scope of trial courts' discretion entails a strict limitation or even prohibition of conditions on forum non conveniens dismissals. ${ }^{103}$ As trial courts currently have not only the discretion to dismiss the case but also the discretion to determine appropriate conditions, limiting or eliminating the capacity to impose conditions would at first glance appear to reduce the discretion of trial courts.

However, such an understanding rests on a particular conception of what "narrowing" entails, as well as on the partitioning of the process into two distinct steps-dismissing and conditioning. Once the discretion of the judge has been unleashed, perhaps narrowing might better be understood to involve minimizing (or even mitigating) the impact of that discretion. In that case, perhaps a narrowing principle encourages the use of conditions, as each condition placed on the defendant as a term of dismissal reduces the impact of dismissal on the plaintiff.

Moreover, it is difficult to assess ex ante what impact a severe limitation on the use of conditions would have on dismissals - trial courts might be less likely to dismiss given the unavailability of mitigating conditions, benefiting plaintiffs, or courts might continue to dismiss, benefiting the now unconditioned defendants. The relative magnitude of these effects cannot be determined as a matter of logic. If the goal of a presumption of mandatory jurisdiction is to minimize the deviations from courts' statutorily defined jurisdiction, then it is not clear whether this goal is best served by allowing or proscribing conditions. Given this uncertainty, such a narrowing principle is unlikely to present the best means of cabining the discretion of the judge to impose conditions.

b) Analogy to Section 1404(a). Considering the enactment of an express venue-transfer statute, perhaps the directions Congress provided for domestic venue transfers might serve as a useful analogue in considering the appropriate characteristics of international forum non conveniens practice. Trial courts might deploy conditions on dismissals as a means to replicate, to whatever extent possible, the features of a Section 1404(a) transfer, thus mimicking a congressionally endorsed mode of exercising discretion over jurisdiction. While lowering the

103 The Supreme Court's implicit consent to dismissal in Piper where the availability of the alternate forum rested on the defendants' concession to submit to personal jurisdiction in Scotland would seem to be in tension with this position. See Piper, 454 US at 242. 
hurdle of inconvenience the moving party must show, Section 1404(a) compensates the plaintiff with two protections that prior forum non conveniens cases lacked: first, the case can only be transferred to an alternate forum if it could have been brought there by the plaintiff in the first instance; and second, the transferee court is obligated to apply the substantive law that the transferor court would have applied, in order to ensure no change in law detrimental to the plaintiff.

However, limiting courts in forum non conveniens dismissals to parallel conditions found in Section 1404(a) is not a viable option. The requirement that a case only be transferred to an alternate forum if the plaintiff could have originally brought it there would strictly curtail the flexibility of the doctrine, as the foreign alternate forums often lack personal jurisdiction over American defendants. Moreover, in Piper, the Supreme Court affirmed a dismissal to Scotland where the plaintiffs could not have attained personal jurisdiction over the defendants in Scotland, so such a restriction would be inconsistent with existing case law. ${ }^{105}$ The second requirement raises serious practical difficulties in determining detrimental changes in law, and itself would sharply curtail the number of cases in which forum non conveniens might be employed, since the "transferee" court cannot be compelled to apply "transferor" law. Again, such a restriction also directly contradicts existing law, as the Court in Piper held that an unfavorable change in applicable law was not a bar to a forum non conveniens dismissal. ${ }^{106}$ Thus the use of the transfer statute as an analogue to delimit the use of conditions appears fruitless, given the existing case law of forum non conveniens dismissals.

\section{B. The Historical Foundations of Forum Non Conveniens as Source of Guiding Principles}

While the institutional context of forum non conveniens proves unable to provide guiding principles sufficient to discipline trial courts' exercise of discretion in imposing conditions, the historical practice and justifications for changing the place of civil trials suggest that the use of conditions there served the purpose of protecting the plaintiff from any undue burdens associated with the change in forum. Such a purpose might also provide modern federal trial courts with principled guidance in the exercise of their discretion to condition forum non conveniens dismissals.

104 See note 44.

105 The defendants in that case had agreed to submit to the jurisdiction of the Scottish courts. Piper, 454 US at 242.

106 Id at 247. 
1. The historical logic of the place of trial.

The historical practice of determining the proper place of trial for a civil action provides a logic that could guide and limit the discretion of the trial courts in imposing conditions on forum non conveniens dismissals. ${ }^{107}$ Interstate assessments of the appropriate place of trial might be treated as parallel to intrastate venue changes. ${ }^{103}$ However, unlike the case of intrastate venue changes, courts acting in an interstate context have no assurances that the alternate court will in fact hear the case. ${ }^{109}$ As the initial court must dismiss the case, rather than simply transfer it, the dismissal might penalize the plaintiff in a way that a transfer does not-the plaintiff might lose any opportunity to vindicate his or her rights in court. In these circumstances, the court may protect the plaintiff's position by conditioning dismissal on certain equitable guarantees. ${ }^{110}$

Such conditional grants of a motion are not without precedent in common law considerations of the place of trial. In Holmes $v$ Wainwright, ${ }^{111}$ a defendant obtained a preliminary ruling in favor of a change of venue from London to Yorkshire on the grounds that all of the witnesses lived in Yorkshire and that "great expense and inconvenience would be incurred in bringing them up," but the plaintiff presented evidence that one relevant fact arose in London. ${ }^{112}$ The defendant agreed to admit that fact, and the judge ruled to change venue on that condition, stating that "as the defendant is willing to admit the only fact which exists within the venue now laid, all the convenience and justice of the case preponderates in favour" of the change. ${ }^{113}$

As common law courts relaxed the requirements that all convenience had to lie in the defendant's favor and moved towards more of a balancing of convenience, ${ }^{1 / 4}$ they began using conditions to compensate the plaintiff for lost convenience. ${ }^{115}$ As one commentator indi-

107 The historical pedigree of a practice alone does not serve to justify it. Rather, these historical practices reveal a justificatory logic that applies to today's practices.

108 For a general discussion, see Foster, 44 Harv L Rev 41 (cited in note 14).

109 Id at 49-50. See also Currie, 22 U Chi L Rev at 423 (cited in note 32) ("No court has the power to transfer a case to another sovereign.").

110 Foster, 44 Harv L Rev at 50 (cited in note 14) (granting the discretionary common law motion on "such terms as seem equitable" could ensure that "the dismissal may operate for all practical purposes as a change of venue"). See also Currie, 22 U Chi L Rev at 433 (cited in note 32) (suggesting that conditioning dismissals was an "ameliorative power" that could scale "the consequence to the proportions of the miscalculation").

1113 East 329 (K B 1803).

112 Id at 329.

113 Id at 330 .

114 Id (noting that courts increasingly "have listened ... with more indulgence" to requests to change venue for the sake of convenience).

115 One might think that this would leave cases in the most convenient forum, as the defendant would accept conditions where his or her conveniences outweighed any concessions to the 
cates, the courts acquired "large discretion ... to condition the granting of the [change-of-venue] motion on the defendant's abandonment of some of his technical legal rights."116 These conditions include a requirement that the defendant take the case to judgment in a particular term of the court, forgo a writ of error, and proceed to the merits; ${ }^{117}$ a requirement that the defendant specify the nature of his defense and the number of witnesses for an assessment of the balance of conveniences; ${ }^{18}$ and a requirement that the defendant "withdraw his plea of Non est factum, and go to trial ... upon the merits."119 $T$ These conditions served to correct for inconveniences that the change of venue and delay imposed on the plaintiff.

\section{Using historical guidance to limit the use of conditions.}

These historical venue cases are instructive, as they reveal a willingness of English common law courts considering venue transfers to undertake something akin to an equitable assessment of the interests of the parties and of justice and to employ conditions on defendants to protect the interests of the plaintiff. This precedent can provide guidance to courts seeking an equitable adjustment in cases of interstate transfer today. When a plaintiff begins an action in a venue that on balance does not seem most convenient, "the question should be not whether he is to be penalized by a dismissal, but whether the ends of justice might better be served by trial elsewhere, and on what terms. ${ }^{, 20}$ By placing conditions on any dismissal, ${ }^{121}$ the court can ensure that "the dismissal may operate for all practical purposes as a change of venue to the other state." and discretionary nature of forum non conveniens analysis, the particular conditions appropriate in a given case "should be left to the sound discretion of the trial court." the plaintiff's choice of forum should play a significant role in assess-

plaintiff, while refusing them where the cost of the conditions outweighed the defendant's convenience.

116 Foster, 44 Harv L Rev at 45 (cited in note 14).

117 See Foster $v$ Taylor, 1 Durnf \& East 781, 782 (K B 1787).

118 See Evans $v$ Weaver, 1 Bos \& P 20, 20 (Com Pleas 1797).

119 Fenwick v Farrow, 1 Chit 334, 336 (K B 1819) (agreeing to change venue upon defendant's agreement to admit the execution of a bond that legally occurred in the county of the original forum).

120 Foster, 44 Harv L Rev at 50 (cited in note 14) (emphasis added).

121 Such conditions might include (a) the defendant's stipulation to service and waiver of any objections to the venue he has proposed as more appropriate; (b) the defendant's waiver of any statute of limitations defenses accruing since the initiation of the action in its present forum; (c) the defendant posting bond to compensate for the loss of any attachments or liens; and (d) possibly the defendant's cooperation in expediting trial in the other state. See id.

122 Id.

123 Id at 51. 
ing the appropriate conditions ${ }^{124}$-the consequences of the dismissal ought to be "scal[ed]" to the "proportions of the miscalculation,", since dismissal seems "a harsh penalty to visit upon a plaintiff for miscalculation or for carrying notions of legitimate strategy a bit too far. ${ }^{126}$ Underlying such a proposal is the sentiment that forum non conveniens is founded in a consideration of the interests of justice. ${ }^{127}$

\section{THE PRINCIPLED USE OF CONDITIONS}

This Comment proposes relying on the common law history of determining the proper place of trial as a basis for guiding and limiting trial courts' discretion in placing conditions on forum non conveniens dismissals. Once a court has determined that the balance of conveniences weighs toward dismissing the suit in favor of the foreign forum, the court should construct the terms of that dismissal such that the reasonable plaintiff is not unduly penalized for his or her choice of forum. Conditions on the dismissal should serve as equitable compensation for the plaintiff. At the same time, the reasonableness of the plaintiff's initial choice of forum should be a factor in assessing what conditions should be placed on defendants in order to ensure that plaintiffs who acted in bad faith by choosing an inconvenient forum are not rewarded for those choices.

In fact, the conditions courts have placed on forum non conveniens dismissals already reflect an implicit incorporation of these concerns. $^{129}$ The predominance of conditions designed to ensure the prac-

124 Id at 50-51 ("The amount of concessions required of the defendant should depend on how reasonable the plaintiff was in beginning the action where he did.").

125 Currie, 22 U Chi L Rev at 433 (cited in note 32).

126 Id at 432. Currie goes on to note that the "plaintiff in the Gulf [Oil v Gilbert] case filed the action in a forum to which he was invited by the venue statute, as construed. He did so without any reprehensible purpose to vex, harass, oppress, or gain an unfair advantage." Id.

127 See Justice Cardozo's dissent in Rogers v Guaranty Trust Co, 288 US 123, 151 (1933) ("The doctrine of forum non conveniens is an instrument of justice."). See also Sim v Robinow, 19 Sess Cas (4th Ser) 665, 669 (1892) (Lord Kinnear) (finding forum non conveniens dismissal appropriate only where trial in alternate forum was "more convenient for all parties" and "more suitable for the ends of justice"); text accompanying note 28.

128 A court should be able to assess the reasonableness of a plaintiff's choice of forum by reference to fairly objective criteria-in fact, by reference to many of the same factors employed in the assessment of whether or not forum non conveniens dismissal is itself appropriate. Insofar as the factors seek to capture the degree to which the cause of action implicates the public and private interests of the forum, they are suggestive of the reasonableness of bringing the cause of action in that forum. Indications of connection between the plaintiff's legal theory of the case and the forum, such as the location of evidence, witnesses, or the occurrence of relevant events, hold particular relevance to this inquiry. As suggested above, these indicia of reasonableness serve as an equitable yardstick for assessing the appropriate degree of conditions.

129 An implicit consideration of such concerns might be divined in both contemporary cases imposing conditions and in the historical examples of conditions at common law, where Currie refers to their use as an "ameliorating power" and as "devices for softening the blow of dismissal which are established concomitants of the doctrine on the international level." See Currie, $22 \mathrm{U}$ 
tical availability of the proposed alternate forum seems in keeping with this proposition, as does the relative reluctance of the courts to intrude into the operations or to question the adequacy of the alternative forum. The current pattern of conditions deployed by the federal courts suggests an underlying goal of placing plaintiffs in the position in which they would have been had they instituted the action originally in the alternate forum, though the courts fail to articulate such a basis expressly. Where conditions have extracted greater concessions from defendants, they might reflect courts' implicit recognition of some reasonable elements in the plaintiffs' decision to sue in the initial forum..$^{130}$ In order to discipline the use of conditions through reasoned legal principles, courts must make this unconscious recognition of the need to protect reasonable plaintiffs from undue burdens an explicit part of their analysis.

One federal circuit court has expressly acknowledged that considering the impact of dismissal on the plaintiff is a necessary component of forum non conveniens analysis. In Pain $v$ United Technologies Corp ${ }^{131}$ the D.C. Circuit suggested a four-step approach to forum non conveniens. First, the court must establish the existence of an adequate alternate forum with jurisdiction. Then the court considers the balance of private factors, and should those fail to be dispositive, the balance of public factors. Finally, if the court determines that the balance favors the foreign forum, the court ought to undertake to redress any undue burden the dismissal places on the plaintiff. ${ }^{122}$ After laying out this test, the D.C. Circuit proceeded to consider the conditions the trial court applied and found them appropriate to "secure adequate alternative forums" for the plaintiffs. ${ }^{133}$ The D.C. Circuit's consideration of the impact of dismissal on the plaintiff in its test for forum non con-

Chi L Rev at 433 \& n 81 (cited in note 32).

130 For instance, evidentiary conditions might have been appropriate in Piper, 454 US at 242 , where the plaintiffs' suit was based in part on claims of defective manufacture, the evidence for which was in the United States. See note 61.

131637 F2d 775 (DC Cir 1980).

132 Id at 784-85 ("If he decides that the balance favors such a foreign forum, the trial judge must finally ensure that the plaintiffs can reinstate their suit in the alternate forum without undue inconvenience or prejudice.").

133 Id at 785 ("By entering dismissal only on the condition that UTC agree to submit to the jurisdiction of the various foreign courts ..., Judge Hart ensured that the defendant would both appear and defend in an alternative forum. By requiring the defendant not to contest liability in those foreign jurisdictions and to proceed to trial only on the issue of damages, he exacted a concession from UTC as the price for permitting it to shift the case from plaintiffs' chosen forum. By requiring waiver of foreign statutes of limitation, he effectively forced UTC to waive any advantage it might have gained from delay. Finally, by expressly providing that the suits could be reopened in the United States without prejudice should any of the stipulated conditions fail to materialize, Judge Hart protected the plaintiffs' right to reinstitute and try the case while simultaneously encouraging plaintiffs to try that case in a nation more closely connected to the event giv. ing rise to that suit."). 
veniens provides an incipient model for the doctrinal incorporation of the concerns highlighted by the history of the place of trial.

\section{A. Policy Justifications of the Proposed Standard for Limiting Forum Non Conveniens Conditions}

On a policy level, any proposal to delimit and direct the scope of a trial court's discretion to condition forum non conveniens dismissals should be assessed by its practical consequences, both in terms of assuring equitable outcomes and creating desirable incentive effects. The highly contextual and fact-based nature of the complex weighing of interests that courts must undertake in these decisions calls for a discretionary consideration of a wide range of factors by the trial court. However, in order to guide these conditional dismissals, as well as to review them, some conception of the scope or purpose of that discretion is necessary. The foregoing analysis suggests that protecting the interests of the reasonable plaintiff is one viable and historically grounded understanding of the purpose of placing conditions on forum non conveniens dismissals. This includes assuring access to some forum, which entails efforts to bring forum non conveniens dismissals more in line with the effects of venue transfers, and also possibly compensating reasonable plaintiffs for their losses in convenience as a result of the forum transfer.

Under the proposed approach, conditions designed to ensure both the technical and the practical availability of an alternate forum ${ }^{134}$ are generally appropriate. As they simply seek to recreate the action as if it had been initially filed in the alternate forum, such conditions generally impose only minor costs on defendants. ${ }^{135}$ Such conditions place few burdens on the defendant that would not have arisen had the suit been filed initially in the defendant's preferred forum, while the failure to impose such conditions would in effect penalize plaintiffs for seeking to vindicate their legal rights consistent with the jurisdictional laws of the forum. Admittedly, the use of such conditions may marginally increase the incentive for plaintiffs to file in the United States as such conditions would alleviate the risks of outright dismissal, but any such impact is likely to be minimal in relation to preexisting incentives to pursue a U.S. forum. In fact, such conditions might create a disincentive for defendants to advocate dismissal on disingenuous grounds.

But in cases where the plaintiff could not have originally obtained jurisdiction over the defendant in the foreign forum, one might

134 See Part I.C.1.a.

135 To the extent that such conditions do impose some minimal costs on defendants, it should be remembered that they are the motivating party behind the change of forum. 
fear that use of conditions would enable plaintiffs to manufacture jurisdiction over the defendants in the foreign court by bringing an initial suit in the United States. However, the concern over the ability of the plaintiff to "import" a concession to personal jurisdiction is tempered by the fact that it is reasonable for the plaintiff to seek to vindicate her rights or seek redress in whatever forum is available to her, and the defendant has advocated the alternate forum as more convenient. ${ }^{136}$ Finally, while any dismissal in favor of a foreign court holds some implication for that court, conditions designed to ensure access to the foreign forum are unlikely to raise issues based in comity, as they do not implicate the internal operation of the foreign court.

Where courts adopt conditions that appear more as compensatory measures, ${ }^{137}$ these impositions deserve more searching scrutiny. The potential for plaintiffs to abuse compensatory conditionsnamely, foreign plaintiffs using compensatory conditions as a means to import American procedural and perhaps even substantive protection back to the more appropriate forum - is troublesome in two respects. First, the possibility of compensatory conditions creates incentives for plaintiffs to pursue their suits in the first instance in U.S. courts with an eye toward gaining some advantage even if the litigation ultimately occurs in some foreign forum. Second, compensatory conditions are more likely to present substantial intrusions into the operations of foreign courts and the actual course of the trial abroad, and thus raise more significant comity concerns.

Given these concerns, the use of compensatory conditions should be strictly curtailed. Here the use of reasonableness as a yardstick is particularly essential. Compensatory conditions should be reserved for cases where the plaintiff had legitimate reasons to choose the forum beyond gaining jurisdiction over the defendant or more favorable law-ideally, some clear connection of the cause of action to the forum. In this narrow class of cases, limited evidentiary conditions might reasonably serve to protect the legitimate interests of plaintiffs against the foreign courts' inability to compel production of relevant information (though the reluctance of courts to impose full discovery ${ }^{133}$ makes sense, since it would create significant incentives for plaintiffs to seek to "import" favorable U.S. law to another court, and would have larger comity implications as well, since such impositions suggest that local discovery procedures are inadequate). Other sorts of equitable adjustments narrowly tailored to the particular circumstances of the case

136 To the extent that this concern remains, it might be dealt with more fruitfully (and perhaps more appropriately) through reform of jurisdiction and venue statutes than by limiting the discretion of a court to impose conditions on forum non conveniens dismissals.

137 See Part I.C.1.b.

138 See text accompanying notes 65-66. 
at hand might also be appropriate in unique cases. ${ }^{139}$ More extreme measures requiring concessions of liability or similar substantive concessions, however, ought to be reserved for the most exceptional circumstances, if they are to be employed at all, as they magnify concerns both with comity and with the plaintiff's incentives.

\section{B. A Recognition of Institutional Concerns}

The desirability of a policy alone does not conclude the inquiry. Courts must also have the institutional authority to adopt a policy. As a general matter, the actions of courts are most legitimate when they have at least implicit legislative warrant. Moreover, legislative control of jurisdictional matters, though foreign to the common law, has sanction in the more common American practice of regulating jurisdiction by statute. ${ }^{\text {1*0 }}$ Yet commentators have expressed skepticism about the likelihood of legislative attention to this area.

As a practical matter, in light of the fact that federal district courts do now exercise discretion in applying the doctrine of forum non conveniens and imposing conditions on the resulting dismissals, adding a standard for directing and assessing such impositions of conditions creates little additional concern with the allocation of institutional authority. Moreover, since the institutional legitimacy of forum non conveniens itself is questionable, courts can use conditions under the proposed standard to cabin its more deleterious effects. Finally, the foundation of the use of conditions in historical practices might temper these institutional concerns. However, the reality of these practices does not undermine the desirability of the legislature endorsing such actions by enacting pertinent jurisdictional statutes.

\section{CONCLUSION}

The use of conditions in forum non conveniens dismissals should be directed and delimited by the principle of protecting the plaintiff's position in proportion to the reasonableness of her initial choice of forum. This principle would guide the discretion of the trial court in

139 For an example of such an instance, see Blanco $v$ Banco Industrial de Venezuela, 997 F2d 974 (2d Cir 1993), discussed in the text accompanying note 68.

140 See note 95.

141 See Dainow, 29 Ill L Rev at 888 (cited in note 13) (calling legislation a "remote" possibility, but noting the existence of two state statutes banning certain tort suits by foreigners); Foster, 44 Harv L Rev at 52 (cited in note 14) ("No matter how little dispute there is as to the desirability of such legislation, there is comparatively little chance of overcoming legislative inertia."). Foster also stated that legislation ought to be general in character. Foster, 44 Harv L Rev at 52. Note, however, that both Foster and Dainow wrote prior to the passage of Section 1404(a), which suggests more reason to believe legislative attention to such matters is possible, though perhaps exceptional. 
placing conditions on forum non conveniens dismissals by providing the direction and rigor that the doctrine currently lacks, while remaining flexible enough to avoid unduly disrupting the court's ability to make discretionary determinations. The principle has two additional virtues: it makes explicit the purpose of placing conditions on these dismissals, and the weighing of the reasonableness of plaintiff's choice of forum assures an equitable response. Moreover, such a principle has support both in the common law history of determining the appropriate place of trial and in the policy outcomes it produces. This historical pedigree reveals that the use of such a principle would not be a radical innovation of the courts but rather a return to the historical practice of conditioning venue transfers to ensure equity to the plaintiff. Though the existing practice of conditioning forum non conveniens dismissals possibly reflects an intuitive concern for plaintiffs' lost conveniences, courts should rely on explicit consideration and reasoned analysis of these competing concerns in conditioning forum non conveniens dismissals. 


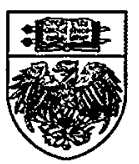

